Bangladesh Rice J. 20 (1) : 33-43, 2016

\title{
Comparison of Tegra and Conventional Rice Cultivation in Bangladesh
}

\author{
A K M S Islam, M A Rahman¹, A B M Z Rahman², M Rahman² and Y J Kim¹
}

\begin{abstract}
Tegra practice (healthy seedling, mechanical transplanting, herbicide application and advisory services), as a new concept in commercial rice cultivation, needs to be evaluated with farmer's practices in our country. This study was conducted in the farmers' field during Aman 2013 and Boro 2013-14 seasons in Bogra district. In each season, six farmers within one kilometer radius were selected to conduct this study. Randomized complete block design (RCBD) with two treatments namely farmer's practices (FP) and Tegra practices (TP) were used in the experiment. Self-propelled four rows walking-type rice transplanter was used to transplant seedling in TP. Seedlings were raised in plastic tray to use in mechanical transplanter. The mat seedlings were ready to transplant when attained 3-4 leaves and 10-12 cm height. Mechanical transplanting found faster than manual transplanting. Missing/floating hill observed insignificant in mechanically transplanted field. Fuel consumption of mechanical transplanter obtained $4.5 \mathrm{~L} / \mathrm{h}$. Tender aged seedling was used in TP and seedling age was higher in FP than TP. Plant height followed the similar trend in both the practices. Tillering ability obtained the highest in TP than FP. TP produced significantly higher $(14-23 \%)$ grain yield in both seasons. The total cost of production, gross return, gross margin and BCR obtained the highest in TP. BCR showed 5-13\% higher in TP than FP in both the seasons due to higher grain and straw yield. The economic analysis clearly revealed the profitability of TP over FP in both the seasons.
\end{abstract}

Key words: Fuel, missing hill, spacing, hill density, input cost, yield, benefit-cost ratio

\section{INTRODUCTION}

In Bangladesh, rice is grown in the three distinct seasons namely Aus, Aman and Boro. Aus rice is grown in March to August. Transplanted Aman (T. Aman) is grown from July to December, while Boro rice is grown mainly under irrigated conditions and planted in December-January and harvested in April-May. There are many ways to transplant seedling-manual, mechanical, throwing. Transplanting of seedlings into heavy puddled soils is the common practice of rice cultivation in Bangladesh. Farmers typically prepare land by two passes of dry tillage followed by exposure to sun for a few days and then inundation of the field, ploughing and harrowing with standing water. Manual paddy transplanting appeared as tedious, laborious and time consuming operations requiring about 123-150 man-h ha-1 which is $19-22 \%$ of total labour requirement of rice production (Islam et al., 2015). It was reported that a delay in transplanting by one month reduces the yield by $25 \%$ and a delay of two months reduced the yield by $70 \%$ (Rao and Pradhan, 1973). Further, due to rapid industrialization and migration to urban areas, the availability of labour became very scarce and with hike in the wages of labour, manual transplanting found costly leading to reduced profits to farmers. Under such circumstances a less expensive and labour saving method of rice transplanting without yield loss is the urgent need of the hour (Tripathi et al., 2004). Mufti and Khan (1995) found $30 \%$ increase in yield and a reduction of about $70 \%$ in labour requirements in

${ }^{1}$ Bangladesh Rice Research Institute, Gazipur, Bangladesh; ${ }^{2}$ Syngenta Bangladesh Limited, Bangladesh. *Corresponding author's E-mail: akmsaifulislam68@gmail.com 
transplanting with machine compared to the manual transplanting. Manjunatha et al. (2009) reported the breakeven area of Chinese made 8-row self-propelled rice transplanter (Model: 2 ZT-238-8) was at least 28 hectares per year. Their results indicated that the cost of mechanical transplanting per hectare was about $51 \%$ lower than that of manual transplanting. The mechanical transplanting of rice has been considered the most promising option, as it saves labour, ensures timely transplanting and attains optimum plant density that contributes to high productivity. Rice transplanters are considerably expensive for almost all Asian small-hold farmers. It is popular in industrialized countries where labour cost is high, for example in South Korea. According to above and necessity of time saving and crop yield, in recent years new models of rice transplanting machine have been introduced in the country and farmers were encouraged to adopt mechanized methods of rice transplanting.

Syngenta, a joint venture company of Syngenta AG Switzerland and BCIC, Bangladesh came forward to start business on mechanized transplanting in the name of Tegra, which is called rice solution in other words. It is a brand name developed by Syngenta. Tegra package consisting of planting high quality seeds coated with seed treatment, raised seedlings, mechanical rice transplanting, labour for logistics while transplanting, and application of herbicides at the time of transplanting, besides advisory on agronomic practices. Rice seedlings are established by the company in a special media comprising rice husk, soil, ash, press mud, nutrients and chemicals. Tegra starts in our country during Aman 2012. Mechanical transplanting is a crucial part to success of Tegra business. It is hypothesized that Tegra practice is cost effective in commercial rice cultivation and produce more grain yield than farmer's practice. Hence, the present study was undertaken to evaluate the Tegra package in the farmers' field.

\section{MATERIALS AND METHODS}

This study was conducted in the farmers' field under Bogra district in Kodma, Omorpur, Nandigram during Aman 2013 season and Amin Nagar, Nandigram during Boro 2013-14 season. The soil type was clay loam (Sand 0\%, Silt 3\% and Clay 97\%), AEZ 25 level Barind tract. Figure 1 shows the weather condition during the experimental period. This experiment was carried out in randomized complete block design (RCBD) with two treatments, viz 'farmers' practices (FP) and Tegra practices (TP). In each season, six farmers within one kilometer radius were selected to conduct this study. The field was prepared using common tillage practice, which is first ploughing (primary tillage) once, followed by puddling (secondary tillage) twice and leveling using two-wheel tractor under the flooding conditions. After first rotatilling, the field was flooded with water and kept as such for seven days and then second rotatilling was done on 8th day and the field was leveled by a plank. The plastic trays were used to raise mat-type seedlings. Dry soil was filled in tray in such a

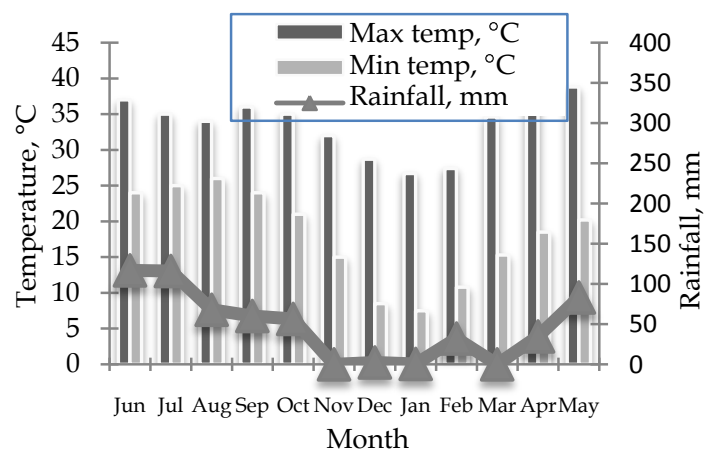

Fig. 1. Temperature and rainfall distribution during experimental period (2013-14). 
way that the soil was free from any stone, stubble and grass. Syngenta developed recipe was used to fill tray for seedling establishment. Sprouted seeds were spread uniformly over the tray by using mechanical sowing line. To protect the seeds from the birds, the mats were covered with black net. Water was sprinkled normally twice a day by rose cane until there was complete emergence of seedlings. The mat seedlings were ready to transplant when they had 3-4 leaves and 10-12 $\mathrm{cm}$ height. Seedbed preparation often involves secondary tillage by using spade and puddling was done after inundating the field. Drainage canals were constructed for proper water removal. Puddled soil was leveled and raised to $5-10 \mathrm{~cm}$ height. Organic manure (decomposed) and a small amount of inorganic fertilizer was applied as basal dressing to increase seed vigour and allows easier uprooting for transplanting. Sprouted seeds were broadcast in the seedbed.

Tables 1 and 2 show the rice variety, seed rate, seedling characteristics in Aman and Boro seasons. Self-propelled four rows walking-type rice transplanter (Asia Transplanter) was used to transplant seedling. It has a fixed row spacing of $30 \mathrm{~cm}$ and has provisions for adjustments of planting depth, number of seedlings per hill and hill spacing. Before starting the transplanter, all the required adjustments as hill spacing, number of plant per hill and planting depth were done based on the machine operator's manual and other agronomical aspects. Tables 3 and 4 show comparative input in two practices in Aman and Boro seasons. Seedling age was higher in FP than TP. Rice variety, fertilizer rate, cultural practices, disease infestation depended on rice season. Proper care was taken and agronomic services were provided regularly in TP. Data on fuel consumption, planting depth, number of seedlings per hill, hill spacing, number of missing hill, floating hills, effective tiller and plant population were collected in both the seasons. Grain yield were recorded from pre-selected $10 \mathrm{~m}^{2}$ land area and adjusted moisture content at the $14 \%$ moisture level. For computing yield contributing characters, four hills were collected from outside the selected area. Panicle number of each hill was counted to determine the panicle number $\mathrm{m}^{-2}$. Plant samples were separated into straw and panicles. Panicles were hand-threshed and the filled spikelets were separated from unfilled spikelets. Spikelets per panicle, grain-filling percentage and harvest index were calculated.

Table 1. Seedling characteristics during Aman 2013 season.

\begin{tabular}{lll}
\hline Parameter & TP & FP \\
\hline Variety & BRRI dhan49 & BRRI dhan49 \\
Date of seeding & 6 Jul 2013 & 6 Jul 2013 \\
Seed rate & 150 gm dry seed tray-1 & $37.5 \mathrm{~kg} \mathrm{ha}^{-1}$ \\
Seedling raising technique & Plastic tray method & Traditional seedbed \\
Seedling raising media & Syngenta developed media & Farmers' nursery bed $^{\prime}$ \\
Date of transplanting & 26 Jul 2013 & 31 Jul 2013 \\
Age of seedling & 16 days & 20 days \\
\hline
\end{tabular}

Table 2. Seedling characteristics during Boro 2013-14 season.

\begin{tabular}{lll}
\hline Parameter & TP & FP \\
\hline Variety & BRRI dhan28 & BRRI dhan28 \\
Date of seeding & 20 Dec 2013 & 20 Dec 2013 \\
Seed rate & 150 gm dry seedtray ${ }^{-1}$ & $37.5 \mathrm{~kg} \mathrm{ha}^{-1}$ \\
Seedling raising technique & Plastic tray method & Traditional seedbed \\
Seedling raising media & Syngenta developed media & Farmers' nursery bed \\
& & 1 Feb 2014 \\
Date of transplanting & 18 Jan 2014 & 42 days \\
\hline
\end{tabular}


Table 3. Comparative inputs during Aman 2013 season.

\begin{tabular}{|c|c|c|c|}
\hline Parameter & $\mathrm{TP}$ & $\mathrm{FP}$ & Remarks \\
\hline \multirow[t]{3}{*}{ Basal Fertilizer } & TSP- 105 kg ha-1 & TSP- 105 kg ha-1 & \\
\hline & MOP-75 kg ha-1 & MOP-75 kg ha-1 & \\
\hline & Gypsum- 60 kg ha-1 & Gypsum- 60 kg ha-1 & \\
\hline \multirow[t]{3}{*}{ Micro Nutrient } & Grozin-7.5 kg ha-1 & Grozin- 7.5 kgha-1 $^{-1}$ & \\
\hline & Bingo-2.5 kg ha-1 & & \\
\hline & Megma-15 kg ha ${ }^{-1}$ & & \\
\hline Weedicide & Rifit + Laser $\left(1\right.$ litre $\left.+130 \mathrm{gm} \mathrm{ha}^{-1}\right)$ & Rifit (1 Litre ha-1) & \\
\hline Time of application & $30 \mathrm{Jul} 13$ & 3 Aug 13 & \\
\hline Weeding & No manual weeding & No manual weeding & \\
\hline \multirow[t]{3}{*}{ Top dressing } & Urea-187 kg ha-1 & Urea-150 kg ha-1 & \\
\hline & MOP-37kg ha-1 & MOP- 56kg ha-1 & \\
\hline & & DAP-56kg ha-1 & \\
\hline 1st top dress & Urea- $75 \mathrm{~kg} \mathrm{ha}^{-1}$ at $15 \mathrm{DAT}$ & Urea-75 kg ha-1 at 21 DAT & \\
\hline 2nd top dress & Urea-75 kgha-1at 30 DAT & & \\
\hline \multirow[t]{3}{*}{ 3rd top dress } & Urea-37 kg ha-1 & Urea-75 kg ha-1 & Late application of more \\
\hline & MOP-37 kg ha-1 at 41 DAT & MOP-56 kg ha-1 & urea and DAP in FP, \\
\hline & & DAP-56 kg ha-1at 55 DAT & $\begin{array}{l}\text { tiller and vegetative } \\
\text { growth enhance at } 60 \text { to } \\
80 \text { DAT in FP. }\end{array}$ \\
\hline Thiovit (sulfur) & $\begin{array}{l}\text { Thiovit-1 kg } \\
\text { at } 15 \text { DAT }\end{array}$ & $\begin{array}{l}\text { Thiovit-1 kg } \\
\text { at } 21 \mathrm{DAT}\end{array}$ & \\
\hline \multirow[t]{2}{*}{ Insecticide } & Virtako- $75 \mathrm{gm} \mathrm{ha}^{-1}$ & Virtako- $75 \mathrm{gm} \mathrm{ha}^{-1}$ & BPH was $10 \%$ in Tegra \\
\hline & Plenum- 300gm ha-1 & Plenum- 300 gm ha-1 & $\begin{array}{l}\text { and } 20 \% \text { was in FP than } \\
\text { immediately take action. }\end{array}$ \\
\hline \multirow[t]{3}{*}{ Fungicide } & Amister Top- $500 \mathrm{ml} \mathrm{ha}^{-1}$, & Amister Top- $400 \mathrm{ml} \mathrm{ha}^{-1}$, & False smut was $5 \%$ in \\
\hline & Filia- 1 litre ha-1 & Filia- $1 \mathrm{~L} \mathrm{ha}^{-1}$ & Tegra and $15 \%$ was in \\
\hline & Score- 500 ml ha-1 & Score- $400 \mathrm{ml} \mathrm{ha}{ }^{-1}$ & \\
\hline Date of maturity & 14 Nov 13 & 20 Nov 13 & $\begin{array}{l}\text { Tegra can be harvested } 7 \\
\text { days earlier than FP }\end{array}$ \\
\hline
\end{tabular}

Table 4. Comparative inputs during Boro 2013-14 season.

\begin{tabular}{|c|c|c|c|}
\hline Parameter & $\mathrm{TP}$ & FP & Remarks \\
\hline \multirow[t]{3}{*}{ Basal fertilizer } & TSP@99 kg ha-1 & TSP@104 kg ha-1 & Farmer used more \\
\hline & MOP@70 kg ha-1 & MOP@110 kg ha-1 & basal fertilizer \\
\hline & Gypsum@60 kg ha-1 & Gypsum@75 kg ha-1 & than Tegra \\
\hline \multirow[t]{3}{*}{ Micro nutrient } & Zn@7.5kg ha-1 & - & \\
\hline & $\mathrm{B} @ 2.5 \mathrm{~kg} \mathrm{ha}{ }^{-1}$ & & \\
\hline & Mg@15 kg ha-1 & & \\
\hline Weedicide & Rifit+Laser@1L+185 g ha-1 & Rifit@750 ml ha-1 & \\
\hline $\begin{array}{l}\text { Time of } \\
\text { application }\end{array}$ & 23 Jan 2014 & 6 Feb 2014 & \\
\hline Weeding & One time harrowing only & 3 times & \\
\hline Top dressing & Urea $185 \mathrm{~kg} \mathrm{ha}^{-1}$ & Urea $280 \mathrm{~kg} \mathrm{ha}^{-1}$, DAP $50 \mathrm{~kg} \mathrm{ha}^{-1}$ & $\begin{array}{l}\text { Farmers applied } \\
\text { more fertilizer }\end{array}$ \\
\hline 1st top dress & Urea 74 kg ha-1 & Urea 120 kgha-1 $^{-1}$ & \\
\hline 2nd top dress & Urea $74 \mathrm{~kg} \mathrm{ha-1}$ & Urea 120 kg ha-1 & \\
\hline \multirow[t]{2}{*}{ 3rd top dress } & Urea $37 \mathrm{~kg} \mathrm{ha}^{-1}$ & Urea $40 \mathrm{~kg} \mathrm{ha-1}$ & \\
\hline & & DAP $50 \mathrm{~kg} \mathrm{ha}^{-1}$ & \\
\hline Cow dung & - & $170 \mathrm{~kg} \mathrm{ha}^{-1}$ & $\begin{array}{l}\text { Used as top } \\
\text { dressed }\end{array}$ \\
\hline Thiovit (sulfur) & $7.5 \mathrm{~kg} \mathrm{ha}^{-1}$ & 4.75 kgha- $^{-1}$ & \\
\hline \multirow[t]{2}{*}{ Insecticide } & Virtako 2 times@ 75 g ha-1 & Virtako 1 times@75 g ha-1 & \\
\hline & Plenum 2 times@300g ha-1 & Plenum 2 times@300 g ha-1 & \\
\hline \multirow[t]{2}{*}{ Fungicide } & Score 1 time@500 ml ha-1 & Score 2 time@500ml ha-1 & \\
\hline & Amister Top 2 times@500ml ha-1 & Amister Top 2 times@500ml ha-1 & \\
\hline Date of maturity & 25 Apr 2014 & 28 Apr 2014 & \\
\hline
\end{tabular}


Border areas of all sides of the plot were excluded to avoid border competition effects. In order to estimate transplanting cost, the data on working speed, total time and labour inputs by the transplanter were recorded. Land value and interest on investment was considered to calculate the total input cost. Price of the produce was collected from the local markets to compute total production cost, gross return, gross margin and benefitcost ratio. Statistical analysis was done by following Gomez and Gomez (1984). Data were analyzed using the ANOVA and the means comparison was determined using Duncan's multiple range tests (DMRT) with the help of the computer package MSTAT-C.

\section{RESULTS AND DISCUSSION}

\section{Fuel consumption}

Fuel consumption in walk behind type mechanical transplanter in both seasons ranged from 4.4-4.6 $\mathrm{L}^{\mathrm{h}} \mathrm{h}^{-1}$ and varied depending on the soil condition. Fuel consumption depended on soil type and operational speed.

\section{Plant spacing and hill density}

In mechanical transplanter, line to line spacing was fixed at $30 \mathrm{~cm}$ whereas, plant to plant spacing can be varied and set at 15 and $17 \mathrm{~cm}$. Figure 2 shows the distribution of plant to plant spacing in actual field condition. In mechanically transplanted plot, hill density ranged from 20.5-21.7 and 18.920.8 in Aman and Boro season respectively. Inconsistent hill density was observed in both the seasons. Exact plant spacing could not be maintained in mechanically transplanted plot due to slippage and skidding of the machine caused by water height, puddled depth and land leveling. In manually transplanted plot, hill density no. $\mathrm{m}^{-2}$ ranged from 14.8-18.3 and 17.46-21.2 in Aman and Boro season, respectively. It might be due to labourers transplanted seedling by eye estimation and unable to maintain proper plant spacing.

\section{Missing hill}

In mechanically transplanted plot, missing hill was observed 1-2\%, which might be treated as acceptable range in crop production. Missing hill largely depended on the seed rate, seed germination, uniformity of seeding and seedling emergence in tray. Seeds having germination of more than $95 \%$ is recommended for seeding in tray to get the uniformity of seedling emergence (Islam and Rahman, 2015).

\section{Number of seedlings dispensed per hill} Figure 3 presents the number of seedlings dispensed per hill in mechanically transplanted fields. Number of seedling dispensed per hill dependent on the seedling density in tray and seedling density setting. Seedling tray requirement in each plot largely depended on the seedling dispensed per stroke. More number of seedling dispensed per hill increased the tray requirement. In practical situation, number of seedlings in each hill varied in different plots. In most of the cases, 1-8 numbers of seedlings dispensed per hill. Single vigour seedling is enough to satisfy agronomic requirement. Calibration should be done on seedling density setting before operation in each plot to get optimum seedling density. To avoid missing hill, number of seedling dispensed should be more than one. 

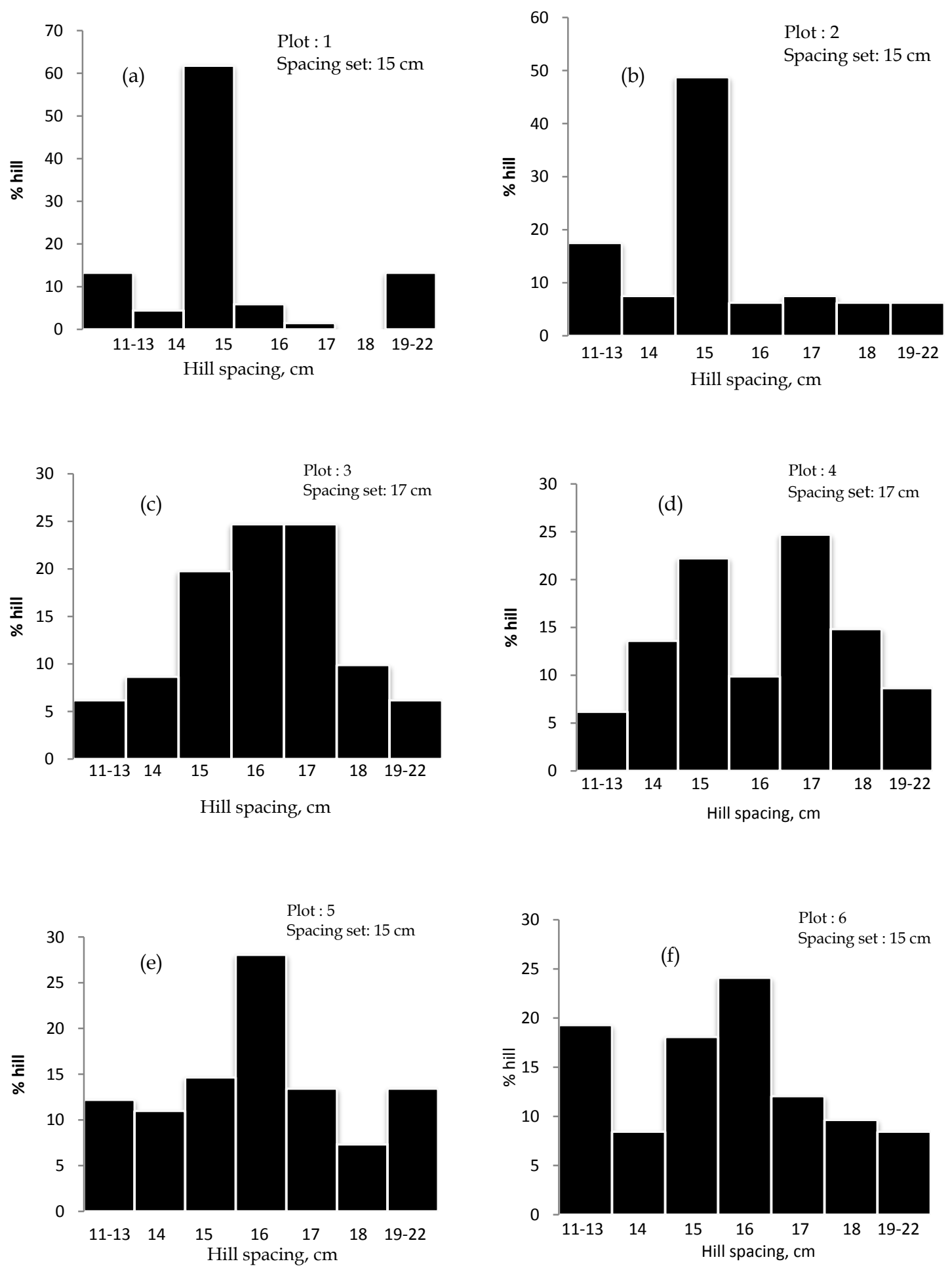

Fig. 2. Hill spacing under different space settings in mechanically transplanted plot. 

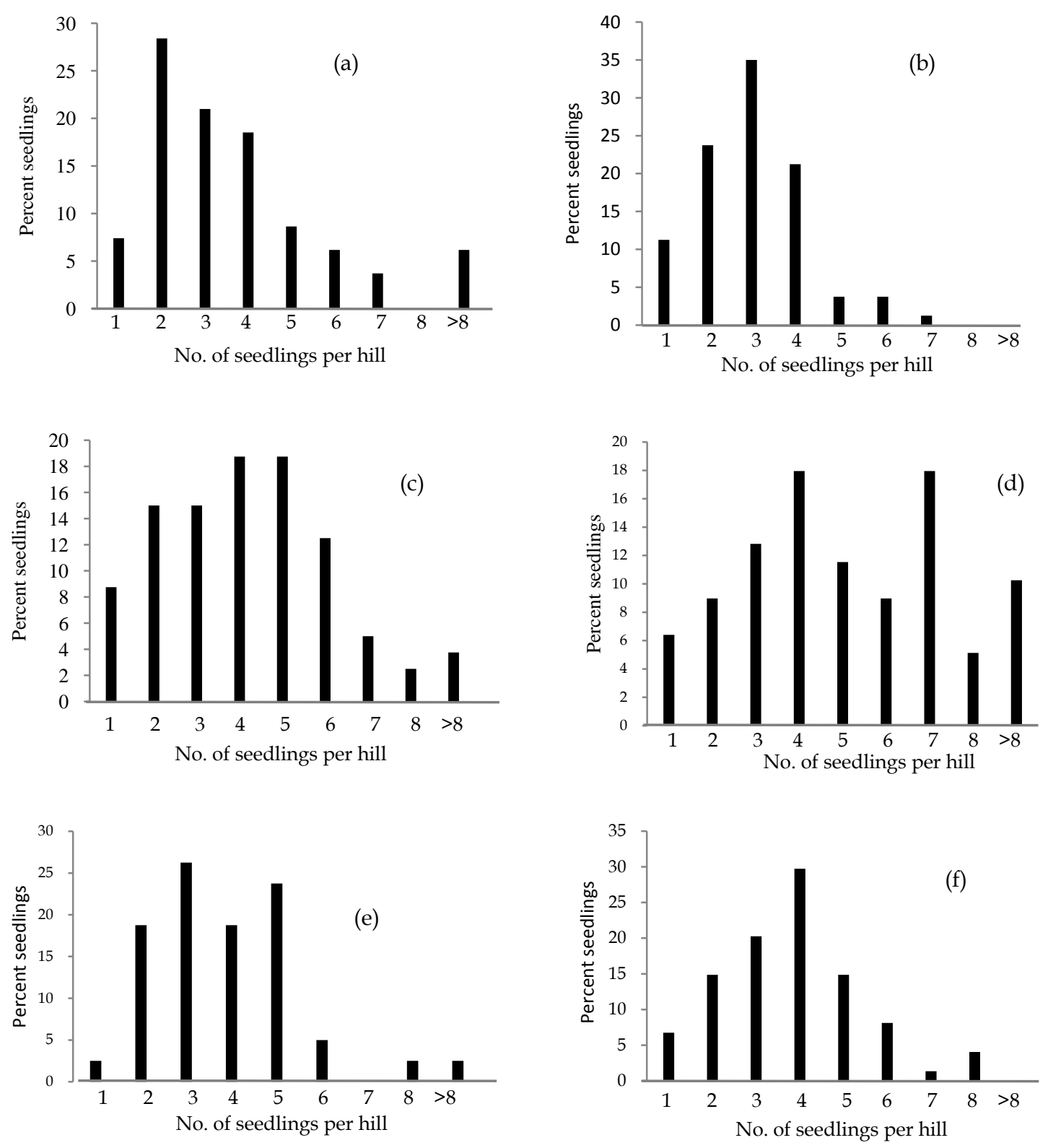

Fig. 3. Seedling density in mechanically transplanted field.

\section{Plant height}

The effects of management practices at different days after transplanting produced significant effect on plant height. Plant height observed similar in both the practices (Fig. 4). Plant height increased progressively overtime attaining the highest at 85 and 100 DAT in Aman and Boro season respectively and there after decreased at the maturity stage. It was due to leaf senescence. Plant height followed rapid growth from 20 to 55 DAT. 

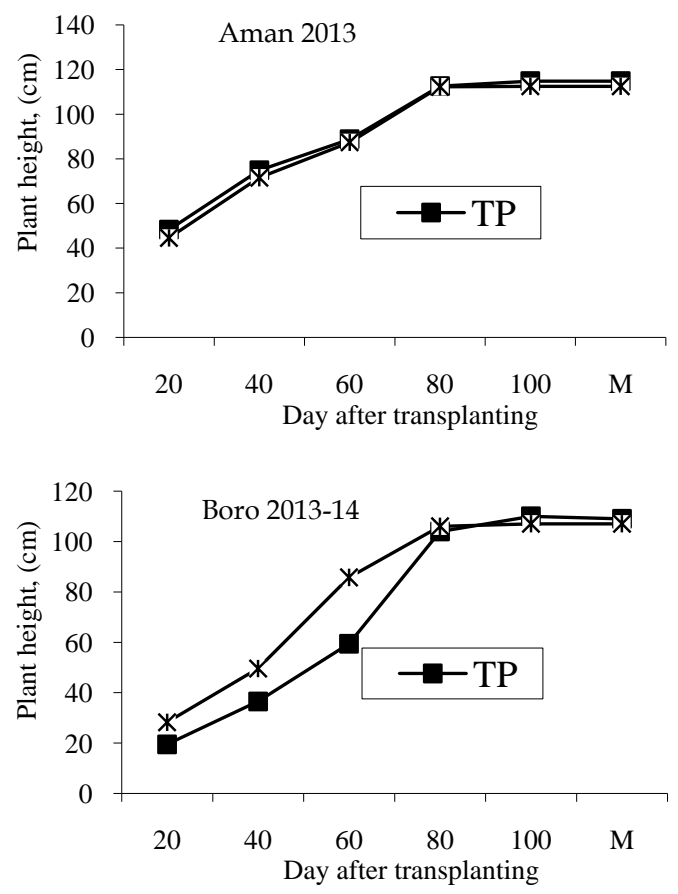

Fig. 4. Plant height in different management practices.

\section{Tillering pattern}

Figure 5 shows the effect of management practices on tillering pattern of Aman and Boro rice. Tillering pattern behaved similarly throughout the production period. Irrespective of management practice, tillering pattern followed increasing trend upto 40 DAT. In both the practices, the tiller production sharply increased from 20 DAT and the maximum tillering stage reached in 40 DAT in Aman and 60 DAT in Boro season and then decreased gradually due to tiller mortality. Tegra practices produced remarkably higher tillers than farmer practices upto maturity stage.

\section{Stage-wise plant population}

Figure 6 shows the stage-wise tiller production under different management practices. Tegra practices produced the highest tillers at all the studied stages and it was more pronounced at maximum tiller and panicle initiation stages. Figure 6 also shows that the highest tiller was produced in TP at the maximum tillering stage. Irrespective of management practices, tiller number was reduced at flowering and maturity stages.
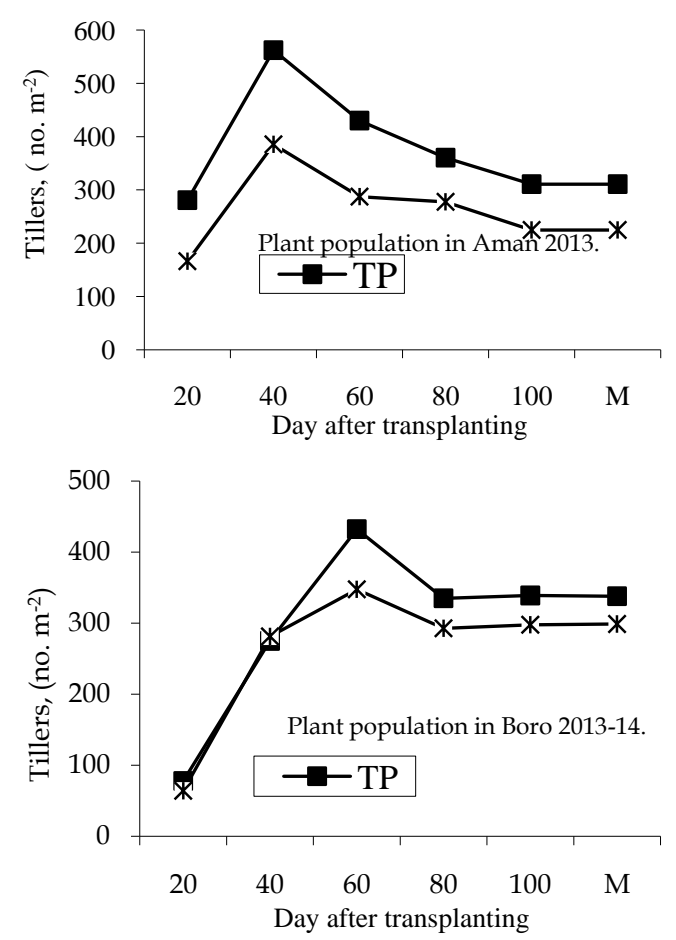

Fig. 5. Effect of management practices on tillering pattern of Aman and Boro rice.
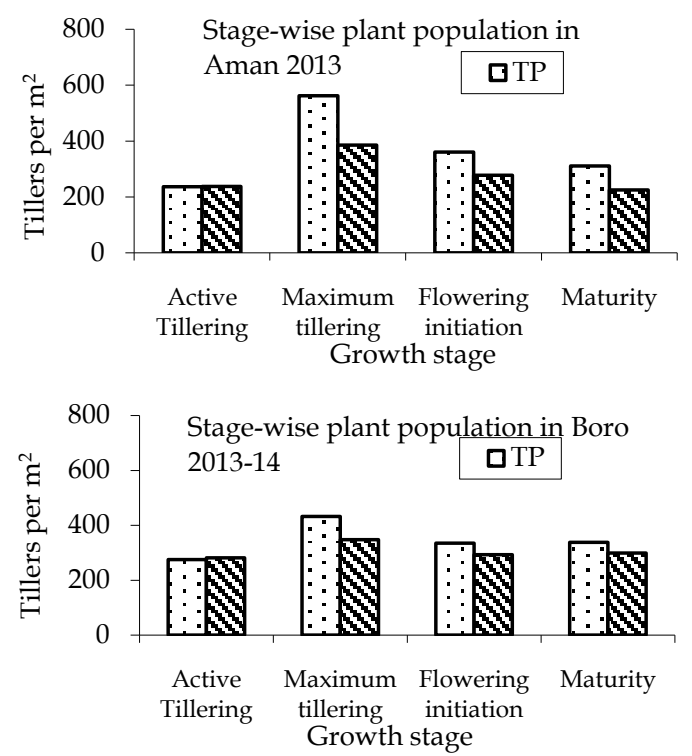

Fig. 6. Growth stage-wise tiller production in different management practices. 


\section{Panicle intensity}

Figure 7 shows the panicle intensity as influenced by TP and FP. The data demonstrated that management practices showed statistically significant effect on panicle intensity in both the seasons.
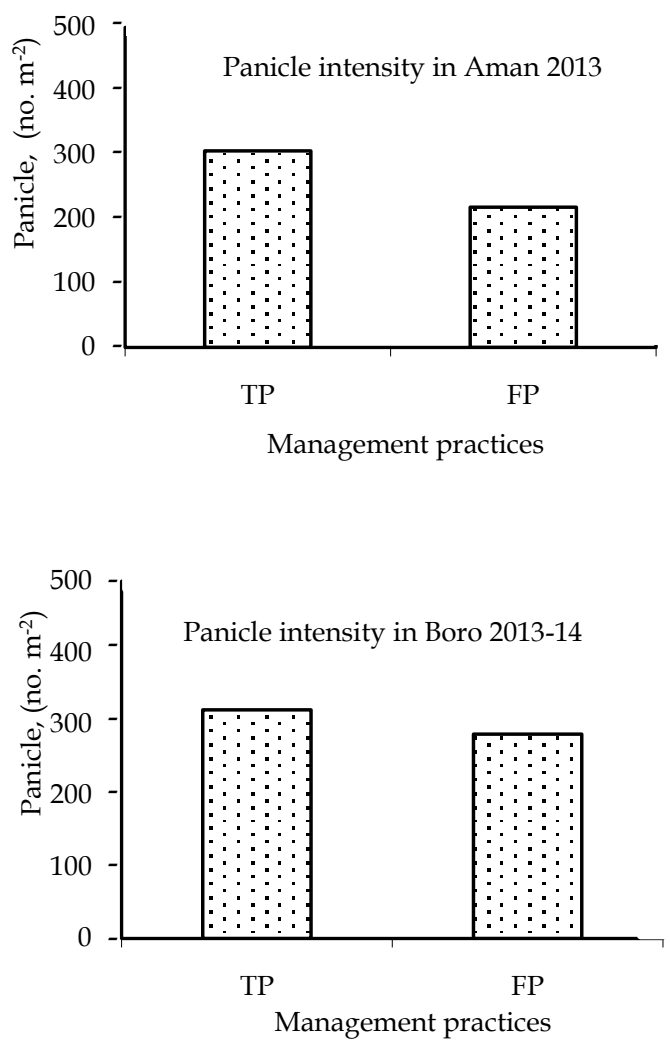

Fig. 7. Panicle intensity as influenced by TP and FP.

\section{Yield and yield contributing character}

Crop matured 3-6 days earlier in TP than FP. Management practices had significant effect on panicle length. TP produced the longest panicle than FP in both the seasons. TP produced the highest grain per panicle than FP. Sterile spikelet production was not significantly affected by management practices. TP produced the highest 1000-grain mass than FP (Tables 5 and 6). Grain yield is a function of interplay of various yield components such as number of productive tillers, spikelets per panicle and 1000-grain weight (Hassan et. al., 2003). TP produced significantly highest grain yield in both the seasons due to use of tender age seedling and good management practices. Grain yield obtained $14-23 \%$ higher in TP than FP in both the seasons.

\section{Economic analysis}

Table 7 shows the price of the product collected from the local market. Table 8 includes all inputs (fuel, labour, irrigation, pesticides, weeding and other expenses) from seedbed preparation to harvesting operations and benefit-cost ratio. Same amount of seed, labour, fertilizer and irrigation water was applied in all the plots of FP. This is not the real farmers' practices.

Farmers always influenced by the Tegra practices and applied more input with a hope to increase yield. The total production cost, gross return, gross margin and $\mathrm{BCR}$ were the highest in TP in two seasons. Production cost was $12 \%$ higher in TP than FP in Aman season due to applying higher input. Input cost was almost similar in Boro season as the farmers applied same input by following the Tegra practices. Gross return was higher in TP than FP due to higher grain and straw yield. Gross margin was higher in TP than FP in both the seasons. BCR was $8-19 \%$ higher in TP than FP in both the seasons due to the higher input cost as well as the higher gross margin compared to FP. TP was more remunerating than FP in both the seasons. 
Table 5. Yield and yield contributing character during Aman 2013 season.

\begin{tabular}{lccccc}
\hline \multicolumn{1}{c}{ Practice } & Panicle length $(\mathrm{cm})$ & $\begin{array}{c}\text { No. of filled } \\
\text { grain panicle }-1\end{array}$ & $\begin{array}{c}\text { No. of unfilled } \\
\text { grain panicle }^{-1}\end{array}$ & $\begin{array}{c}\text { 1000-grain } \\
\text { weight }(\mathrm{gm})\end{array}$ & $\begin{array}{c}\text { Grain yield, } \\
\left.(\mathrm{t} \mathrm{ha})^{-1}\right)\end{array}$ \\
\hline TP & 23.01 & 129.4 & 26.53 & 22.4 & 5.32 \\
FP & 22.16 & 108.8 & 27.11 & 21.9 & 4.66 \\
CV,$(\%)$ & 2.22 & 7.63 & 9.76 & 0.77 & 3.78 \\
Level of significance & $* *$ & $*$ & NS & $*$ \\
\hline
\end{tabular}

Table 6. Yield and yield contributing character during Boro 2013-14 season.

\begin{tabular}{lccccc}
\hline \multicolumn{1}{c}{ Practice } & Panicle length $(\mathrm{cm})$ & $\begin{array}{c}\text { No. of filled } \\
\text { grain panicle }{ }^{-1}\end{array}$ & $\begin{array}{c}\text { No. of unfilled } \\
\text { grain panicle }{ }^{-1}\end{array}$ & $\begin{array}{c}\text { 1000-grain } \\
\text { weight }(\mathrm{gm})\end{array}$ & $\begin{array}{c}\text { Grain yield, } \\
\left.(\mathrm{t} \mathrm{ha})^{-1}\right)\end{array}$ \\
\hline $\mathrm{TP}$ & 23.30 & 112.60 & 30.90 & 23.20 & 6.40 \\
$\mathrm{FP}$ & 24.50 & 122.70 & 37.00 & 22.30 & 7.20 \\
$\mathrm{CV}(\%)$ & 1.97 & 18.24 & 42.78 & 1.34 & 7.24 \\
Level of significance & $*$ & $\mathrm{NS}$ & NS & $*$ & $*$ \\
\hline
\end{tabular}

Table 7. Product name with price.

\begin{tabular}{|c|c|c|c|c|c|}
\hline Name of product & Quantity & Price (Tk) & Name of product & Quantity & Price $(\mathrm{Tk})$ \\
\hline TSP & $50 \mathrm{~kg}$ & 1220 & Plenum & $100 \mathrm{~g}$ & 480 \\
\hline MOP & $50 \mathrm{~kg}$ & 730 & Score & $500 \mathrm{ml}$ & 1110 \\
\hline Urea & $50 \mathrm{~kg}$ & 820 & Amister Top & $500 \mathrm{ml}$ & 1335 \\
\hline Gypsum & $10 \mathrm{~kg}$ & 220 & Rifit & $500 \mathrm{ml}$ & 380 \\
\hline Zinc & $1 \mathrm{~kg}$ & 200 & Laser & $25 \mathrm{~g}$ & 45 \\
\hline Megma & $1 \mathrm{~kg}$ & 105 & Thiovit & $1 \mathrm{~kg}$ & 180 \\
\hline Bingo & $1 \mathrm{~kg}$ & 400 & DAP & $50 \mathrm{~kg}$ & 900 \\
\hline Paddy price & $1 \mathrm{t}$ & 20000 & & & \\
\hline
\end{tabular}

Table 8. Production cost and benefit-cost ratio of TP and FP during Aman 2013 and Boro 2013-14 season.

\begin{tabular}{|c|c|c|c|c|}
\hline \multirow{2}{*}{ Item, Tk ha-1 } & \multicolumn{2}{|c|}{ Aman 2013} & \multicolumn{2}{|c|}{ Boro 2013-14 } \\
\hline & $\mathrm{TP}$ & FP & $\mathrm{TP}$ & $\mathrm{FP}$ \\
\hline Seed & 2805 & 2319 & 2618 & 1309 \\
\hline Seedling raising & 13464 & 3625 & 6508 & 3590 \\
\hline Land preparation & 4488 & 4488 & 6732 & 6732 \\
\hline Basal fertilizer & 8243 & 6859 & 8826 & 6016 \\
\hline Irrigation & 2244 & 2244 & 7480 & 7480 \\
\hline Transplanting & 1122 & 5984 & 2094 & 3740 \\
\hline Herbicide & 1047 & 748 & 898 & 648 \\
\hline Gap filling + weeding & & & 11220 & 14960 \\
\hline Urea top dressed & 3740 & 4563 & & \\
\hline Sulpher + Thiovit & 1346 & 1346 & 4294 & 6024 \\
\hline Insecticide & 4712 & 3815 & 3590 & 2525 \\
\hline Fungicide & 6313 & 4795 & 3642 & 3643 \\
\hline Harvesting + Threshing & 9724 & 9724 & 11220 & 11220 \\
\hline Sub total & 59249 & 50510 & 69121 & 67887 \\
\hline Land value & 20000 & 20000 & 20000 & 20000 \\
\hline Interest on investment ( $12 \%)$ & 1982 & 1764 & 2229 & 2198 \\
\hline Total production cost & 81231 & 72274 & 91351 & 90086 \\
\hline Gross return & 123760 & 101779 & 148397 & 122615 \\
\hline Gross margin & 42529 & 29505 & 57046 & 32529 \\
\hline Benefit-cost ratio & 1.52 & 1.41 & 1.62 & 1.36 \\
\hline
\end{tabular}

42 Islam et al 


\section{CONCLUSION}

Plant spacing of mechanically transplanted plot varied depending on puddled condition, soil type and water height. Plant height followed the similar trend in both the practices. Tillering ability showed the highest in TP. TP showed significantly higher grain yield than FP due to use of tender age seedling and good management practices. Tegra practice was more profitable in Boro than Aman season. It could be promoted extensively in farmer's field to get better yield and economic performance.

\section{RECOMMENDATION}

The results should be validated in different Agro-ecological zone.

\section{ACKNOWLEDGEMENT}

The authors acknowledge the support of Syngenta Bangladesh Limited to conduct the validation trial in two seasons.

\section{REFERENCES}

Gomez, K A and A A Gomez. 1984. Statistical Procedures in Agricultural Research, New York, Chichester, etc.: Wiley, 2nd edition, pp. 680.

Islam, AKM S and M A Rahman. 2014. BRRI-Syngenta Tegra transplanting under public private partnership approach. An unpublished research report submitted to Tegra programme, Syngenta Bangladesh Limited. September 2014.

Islam, AKM S. 2015. Evaluation of mechanical rice transplanter in Rangpur and Jhenaidah district during cold season. An unpublished report submitted to IRRI, Bangladesh.

Manjunatha, M V, B G Masthana Reddy, S D Shashidhar and V R Joshi. 2009. Studies on the performance of self-propelled rice transplanter and its effect on crop yield. Karnataka J. Agric. Sci. 22(2): 385-387.

Mufti, A I and A S Khan. 1995. Performance evaluation of Yanmar paddy transplanter in Pakistan. Agricultural mechanization in Asia, Africa and Latin America. 26 (1): 31-36.

Rao, M V and S N Pradhan. 1973. Cultivation practices. Rice Production Manual, ICAR; 71-95.

Singh, G, T R Sharma and C W Bockhop. 1985. Field performance evaluation of a manual rice transplanter. J. Agric. Engg. Res.,32:259-268.

Tripathi, S K, H K Jena and P K Panda. 2004. Selfpropelled rice transplanter for economizing labour, Indian Fmg., 54: 23-25. 